\title{
IMAGES OF A GOOD VILLAGE: A VISUAL ANALYSIS OF THE RURAL IDYLL IN THE "VILLAGE OF THE YEAR” COMPETITION IN THE CZECH REPUBLIC
}

\author{
Pavel Pospěch ${ }^{1}$, Daniela Spěšná ${ }^{2}$, Adam Staveník
}

Received 5 December 2014; Accepted 12 June 2015

\begin{abstract}
This paper presents a sociological analysis of the image of a "good village", as portrayed in the annual Czech competition Village of the Year. It focuses on the positive representations attached to the rural in the political and expert discourse. The analysis is rooted in cultural rural sociology and in its study of rural idyll. It is argued that a specific kind of rural idyll is produced in the competition. This idyll is analysed using the photographs submitted to the competition by the villages themselves. A combination of visual methods is employed to uncover the positive values attached to the images. The results show that activity and social life play a key role in the image of a "good village" thus produced. On the other hand, there are virtually no references to agriculture.
\end{abstract}

Keywords: Village, rural, village of the year, representations, visual images, Czech Republic

Abstrakt: Tento text sociologicky zkoumá obraz "dobré vesnice" v soutěži Vesnice roku, pořádané každoročně $v$ ČR. Jeho cílem je zjistit, jaké pozitivní hodnoty jsou spjaty $s$ venkovem $v$ současném politicko-expertním diskurzu. Analýza vychází z kulturně orientované rurální sociologie a z jejího zaměření na venkovskou idylu. Text předestírá různé formy venkovské idyly a představuje ideál "Vesnice roku" jako svého druhu idylu, soubor pozitivních obrazů venkova. Empirická část shrnuje výsledky vizuální analýzy fotografií, které obce do soutěže zasílají. Kombinací výzkumných technik identifikujeme obsah fotografií a pozitivní hodnoty s ním spjaté. Výsledky ukazují, že "dobrá vesnice" $v$ soutěži znamená především vesnice s aktivním společenským životem. Naopak vůbec zde není zastoupen obraz zemědělství.

Klíčová slova: Vesnice, venkov, vesnice roku, reprezentace, vizuální obrazy, Česká republika

This research has been supported by Czech Science Foundation Grant No. GA13-40212S "Re-inventing the rural in the post-1989 Czech Republic.

\footnotetext{
1 Mgr. Pavel Pospěch, Ph.D., Masaryk University Brno, Joštova 10; e-mail: pavel.pospech@gmail.com

2 PhDr. Daniela Spěšná, Institute of Agricultural Economics and Information Brno, Kotlářská 53, Brno, e-mail: spesna.daniela@uzei.cz
} 


\section{Introduction}

What is a good village? What makes a good village? These questions invoke the values which our society ascribes to rural areas and to rurality as such. Answers to these questions would vary with time and with context: a 1970s image of a good village would differ from today's image, a farmer's image would differ from the image of an urban tourist. Rurality is indeed an object of historical conflicts of values, interpretations and meanings (Woods \& McDonagh 2011). We study the images of the rural which are produced in the annual competition Village of the year in the Czech Republic. In the competition, rural municipalities use visual images to present themselves as good villages and worthy candidates for the title Village of the year. We study these images in order to find out what values are communicated by them. By means of visual analysis, we look for values which produce the image of a good village in this particular discourse.

The paper is grounded in a cultural approach in rural sociology, building on the assumption that rural images and representations are distinctive and meaningful elements which can be studied with respect to their contents, their functions and their dynamics. We focus on the visual images submitted to the competition by the participating villages since we are convinced that visual images are able to convey meanings and values in a specific way, distinctive from written text, but equally important. From the images of the successful "villages of the year" we can learn what a good village looks like and which features of rural life are valued prominently. Do the pictures show farmers working in their fields? Do they show urban tourists taking pictures of local landmarks? Do they show sport pitches, garden swimming pools, environmentally-friendly technologies? Such questions can help us understand the values which Czech political and expert discourse imposes on rural areas.

The paper will start with a brief description of the cultural turn in rural sociology and the relevant theories of social representations and discourses of rurality. From here, it will advance towards a specific cultural frame of rural idyll. Rural idyll refers to an image of rurality endowed with positive values. The discussion will point out the multiplicity of rural idylls and the discourses which produce them and relate the notion to the positive self-presentation of villages in the competition. We will then introduce the competition itself and the methodology we have used to analyse the data. The results will be arranged by categorised codes, meaningful clusters of iconographic properties, ascribed to the images by the respondents. In conclusion, we will review the emergent codes and values, stress the most frequent ones and point out the absent, albeit expected ones.

\section{Theoretical background: rural self-presentation}

\subsection{Rural representations and rural idyll}

In order to understand how a "good village" is represented in the competition materials, it is necessary to focus on the representations of the rural and rurality. This approach became prominent in rural studies following the cultural turn in rural sociology (Cloke 1997; 2006). Influenced by a general trend towards a culture-focused sociological analysis (Alexander 2003; Nash 2001), this approach has emerged in relation to the process of rural restructuring (Marsden et al., 1990; Woods, 2005), whereby rural areas are seen as moving from their traditional productive, agriculture-centred functions towards multifunctional spaces of consumption. In their new role, rural areas are imbued with new functions, values and meanings. Cultural approaches in rural sociology focus on these meanings, their production, their negotiations and their conflicts.

The cultural focus on the representations of rurality takes cue from Moscovici's theory of social representations (Moscovici \& Duveen 2000). Influenced by Durkheim's notion of collective representations, Moscovici has studied social representations as socially produced bodies of knowledge, which provide their objects with culturally recognisable meaning. This approach has been taken up by Halfacree (1993; 1995) who has applied it to the images of the rural, through which rural areas are recoded and endowed with moral and ideological values. For Halfacree, social representations of rurality are "an amalgam of personal experiences and 'traditional' handed-down beliefs propagated through literature, the media, the state, family, friends and 
institutions" (Halfacree 1993: 33). In a related approach, Jones (1995) and Svendsen (2004) have studied the discourses of the rural as cultural frameworks of meaning through which the rural is produced and reproduced. It has been noted that these have "a constitutive power" (Jones 1995: 36) over their object. In other words, the way we speak about the rural, the way we present it and the symbolic meaning we attach to it all have an influence on the "real" rural areas. Therefore, rural discourses have been studied in terms of their political power potential, both for lay populations and for policymakers (Erjavec et al. 2009; Winther \& Svendsen 2012).

A substantial part of research in cultural rural sociology has focused on the issues of rural idyll (Bell 2006; Bell 2007; Cloke \& Little 1997; Halfacree 1995; Mingay 1989; Short 1992; Williams 1973; Winchester \& Rofe 2005) Rural idyll refers to the "popular imagination" of "bucolic tranquillity and communion with nature" (Bell 1997:94), a normative frame through which positive values are ascribed to the rural and rurality. The notion of rural idyll and the "golden echo" (Williams 1973) of rural life have often been described as urban phantasies about rurality (Duenckmann 2010) which have become dominant in our ways of understanding rurality. In his study of the imagined country, Short has described the idyll of rural life as: more wholesome, more spiritually nourishing, more natural. The country dweller is seen, in the myth, as simpler and less compromised by social convention. The dominant image is of the happy swain close to nature, connected to the rhythms of the earth and the seasons of the year (Short, 1992: 30).

The notion of rural idyll has been studied empirically by a number of authors. Phillips et al. (2001) have focused on elements of rural idyll in British television dramas about rural life. They have identified different ways through which these programmes are being read by the audience, suggesting a more complex view of the way the idyllic images are reproduced. Vepsäläinen and Pitkänen (2010) have studied the idyllic images of rurality in the Finnish popular discourse on second housing. Their research follows Bell's (2006) distinction of farmscapes, wildscapes and adventurescapes as distinct types of rural idyll. They have identified a strong representation of rural idyll as a "middle ground" between the dystopic representations of rural deprivation and the overly idealised images of rural marketing. They have also stressed the biographic dimension of rural idyll and its relation to childhood. In a paper on the portrayal of rurality in lifestyle magazines, Baylina and Berg (2010) have criticised the concept of rural idyll as favouring certain groups, namely middle-class nuclear families.

In the Czech Republic, the notion of rural idyll has frequently been employed in the discourse of rurality, especially in connection to the notion of rural renewal (Pospěch 2014), which has been introduced in the early 1990s. Idyllic representations have been produced by academics and experts as means of stressing the social value of the rural and the need for state intervention in its favour (Hrabánková 1997). The historical development of the myth of rural idyll has been studied respectively by Blažek (1998) and Librová (1996). Blažek's view of the concept has been highly critical, describing rural idyll as a self-deception focused on "our sentimental view of the rural" rather than "what the rural really is like" (1998: 82). Librová has identified elements of the myth of rural idyll in contemporary ecological thought and its arguments for residential decentralisation (Librová 1996: 288). Majerová (2006) has noticed that the idyllic notion of the village as a "shrine of national values" has been ascribed to rurality by the urban imagination.

Building on the tradition of the cultural study of rural idyll, this paper seeks to identify the elements of rural idyll produced and reproduced in the Village of the year competition in the Czech Republic. Before we describe the research design of the paper, we will shortly introduce the competition itself.

\subsection{Village of the year}

The competition Village of the year has been running annually in the Czech Republic since 1995. Its official goal is declared as follows:

The aim of the traditional competition Village of the year in the Programme of rural renewal is to support rural population in their active engagement of the development of their home. It aims to disseminate the variety of the local development programmes in villages and to inform the broad public about the importance of the rural areas. Its further aim is to stress 
the municipal activities and the activities of rural representatives and citizens, who work not only to improve their homes but also to develop local traditions and engage in the life of local community (Quoted from the website of the competition; http://www.vesniceroku.cz).

The competition is organised by the Syndicate for rural renewal (Spolek pro obnovu venkova) in cooperation with the Ministry of Regional Development, Ministry of Agriculture and the Union of Towns and Municipalities in the Czech Republic (Svaz měst a obcí). In the present system, there are various prizes - "ribbons" - to be won in the competition. Different colour ribbons are awarded for achievements in environmental care, community work, work with youth, cooperation with agriculture and civic engagement. The absolute winner is awarded a golden ribbon: one golden ribbon is handed out annually in each region and a country-wide winner is selected among the regional winners. In recent years, more than 250 rural municipalities have participated in the competition annually, attracted by the promise of financial prize, tourist visibility and the possibility to participate in the competition on a pan-European level.

In order to participate in the competition, a village needs to fill in an application form with basic data about the municipality, submit a written text characterising the municipality and pay an entrance fee of 2 CZK per inhabitant. As an attachment, villages are asked to submit ca. 30 photos. The photos should include "postcard" views of the village as well as documentation of the village life. There are no precise requirements on the quality of the photos (amateur, professional) or on the number of the photos submitted. The only condition is that the photos should cover both the visual appearance of the village as well as its social life in its broadest sense. Additionally, villages have an option to submit ca 5 photos of buildings in the village, if they wish to participate in the "Golden Brick" award for "exemplary rural buildings".

In order to analyse the image of a "good village", we have undertaken a visual analysis of the photos submitted with the applications of the competition winners. The photos were received from the Ministry of Regional Development, which is administratively in charge of the competition. In line with the assignment and the conditions of the competition, we have assumed that the images would be chosen with the intent of presenting a positive self-image of the village. On the submitters' side, the selection would be guided by (a) the motif of description, i.e. what the village is like and (b) the motif of valorisation, i.e. what positive values are present in the village. On the side of the recipients (the organisers and the committee), there would be a positive response: if a village wins the golden ribbon, it can be presumed that it satisfies the criteria of a "good village", employed by the recipients of the application. While there are many other criteria the selection is based upon (the application, the presentation materials and an actual visit of the committee), the role of visual self-presentation needs to be stressed, since it is the most important means through which the rural is presented to the gaze of the other (Urry 1990).

It can therefore be safely assumed that the photos submitted to the competition by the eventual winners, are representative of the idea of a "good village" produced in the dialogue between the actual village representatives (the submitter) and the committee (the receiver). This positive representation thus represents a certain kind of rural idyll, a set of images that can be studied and analysed as a meaningful cultural figure. Certainly, the rural idyll thus produced is contextdependent. It is produced by certain actors (municipality representatives, ministerial committee, etc.) for a certain competitive purpose, i.e. a state-organised competition. The idyll will therefore differ from rural idylls and the "golden echoes" produced by popular media (Phillips 2001; Williams 1973) or those produced in market-oriented self-presentation of the commodified rural (Urry 1990; Woods 2005).

With these context issues in mind, the following questions may be asked: what is the nature of the rural idyll produced in the competition? What is the image of a "good village" thus created? What elements make up the idea of a "good village"? What objects, actions, institutions and values are associated with this kind of rural idyll? The photos submitted with the applications were analysed in order to answer these questions. 


\section{Methodology}

The paper is based on a visual methodology, which offers a unique insight into the problem. As Chaplin (1994) has shown, visual images are not merely illustrations or reflections of the text and they contribute to the understanding of social reality in their own right. A study of visual representations is also necessarily based on a cultural understanding of the rural and rurality, as discussed above. The visual data in this study portray the representation of reality, rather than reality itself (see Brandth 1995). This premise should be kept in mind regardless of the fact that the relations between reality and its representations are often considered mutually constitutive in visually oriented sociology (Chaplin 1994).

In order to understand the notion of a "good village", a combination of visual analytic techniques is employed, including elements of content analysis and semiotic analysis. This approach takes cue from Rose's (2001: 202) observation that a combination of visual methods may yield a more detailed picture of the object in focus. Content analysis is recommended by Sztompka (2005) for research designs which include series of photographs of the same theme. It "is a research technique for making replicable and valid inferences from data to their context" (Krippendorf, 1980: 21) which allows us to understand the relationship between the elements of a text or an image and its wider cultural context. At the same time, its procedure is methodologically explicit, allowing the construction of replicable and reliable research designs (Rose 2001: 5556).

Content analysis is based on counting the frequency of certain visual elements in the data. In this study, this means counting the presence of respective codes in the village presentations. These codes are derived from a focus group study, whose members were asked to describe the images shown to them. This step is rooted in semiotic analysis: the focus group members were asked to provide a connotative description, referring not to what actually is in the image, but rather to what the image portrays. In Panofsky's (1981) terms, such description is referred to as iconographic, since it focuses on what the viewer believes the picture shows rather than to a simple description of what she sees in it. Unlike in classic content analysis, such as Lutz and Collins (1993), our design does not rely on the researchers coding the data themselves. Instead of that, we have used the advantage of the focus group design with $N=13$, letting the respondents code the images themselves. The focus group was demographically heterogeneous ( 5 males and 8 females of various age groups) and all its members were professionals in rural and/or agricultural policy. Their background therefore resembled the background of the actual addressees of the images: the ministerial commission in the Village of the year competition.

The respondents in the focus group were asked to code a total of 94 images, randomly selected from the applications of villages which eventually went on to win the Golden ribbon. It was a process of free coding with no intervention from the researchers: the codes therefore reflect the respondents' subjective iconographic reading of the images. Thus, in the resulting matrix, each image has been iconographically described with up to 13 unique codes. In the next step, the research team has grouped these codes into meaningful categories for the purpose of quantification (see Collier \& Collier 1990: 190). In the grouping process, the researchers have focused on preserving the variety of the original focus group codes, rather than reducing it too harshly. Therefore, 46 code categories were identified. The frequencies of these categories were then counted and images which were seen as most representative for the respective categories were identified.

In the second stage, the focus group respondents were shown a second set of 50 pictures, randomly chosen from those submitted by the eventual winners of the competition. This time the focus was not on the description of the picture but on the positive value associated with it. Respondents were asked to write down the positive values that the given picture represents for them; if they did not identify a positive element in the picture, they left the space blank. This stage was different from the previous one. While the previous one has focused on the representation of village in "good village", here, the focus is on goodness. By focusing on what is axiologically being "sold" in the pictures, rather than on what they depict, we tried to capture the emotional appeal of the visual self-presentations. The technique is directly 
connected with the analysis of rural idyll, as it encourages the participants to look for the idyllic representations in the pictures.

\section{Results}

In the first stage, we have concentrated on the iconographic content of the images: what is actually being portrayed in the images which accompany the successful applications? What is there in the villages of the year? The results of the first stage are summed up in table 1.

\begin{tabular}{|l|c|l|c|}
\hline Categorised code & Frequency & Categorised code & Frequency \\
\hline Village renewal & 156 & Church & 22 \\
\hline Community & 100 & Youth & 22 \\
\hline For children & 88 & Neglect & 21 \\
\hline Tradition & 86 & Idyll & 18 \\
\hline Culture & 82 & Free time & 17 \\
\hline Facilities & 78 & Leisure & 16 \\
\hline Landmarks & 71 & Old age & 16 \\
\hline Nature & 51 & Domestic output & 15 \\
\hline Sport & 42 & Unatractiveness & 15 \\
\hline Landscape & 33 & Playground & 14 \\
\hline History & 29 & Village common & 14 \\
\hline Transport & 27 & Firemen & 13 \\
\hline Emptiness & 26 & Attractiveness & 11 \\
\hline Belief & 25 & Modern & 11 \\
\hline Lack of funding & 10 & Animals & 7 \\
\hline Entrepreneurship & 9 & Family & 6 \\
\hline School & 9 & Associations & 6 \\
\hline Tourism & 8 & Alcohol & 5 \\
\hline Ecology & 7 & Authentic countryside & 5 \\
\hline Peace & 7 & & \\
\hline
\end{tabular}

Tab 1. Iconographic content of the images.

As the table suggests, village renewal is the most frequently mentioned category. This notion stems from the official language of public policy: the Programme of Village Renewal and the subsequent Programme of Rural Renewal were implemented by the government from as early as $1991^{3}$ onwards (Vobecká 2009). Figure 1 shows the image chosen by the respondents as the most representative for this notion. The image of a scaffolding-covered church suggests that the notion of renewal is seen as tied to the spiritual and religious landmarks. Community, the second most frequent category, has most frequently been mentioned with figure 2 . There are a number of people of various ages present in the picture who seem to be engaged in a common activity, even though the nature of this activity is not clear. The heterogeneity in age is a striking feature of the image, featuring even young children.

\footnotetext{
${ }^{3}$ The term "rural renewal" itself, however, comes from the German notion of Dorferneuerung. For a more detailed discussion of the concept of renewal in Czech public discourse, see Pospěch (2014).
} 


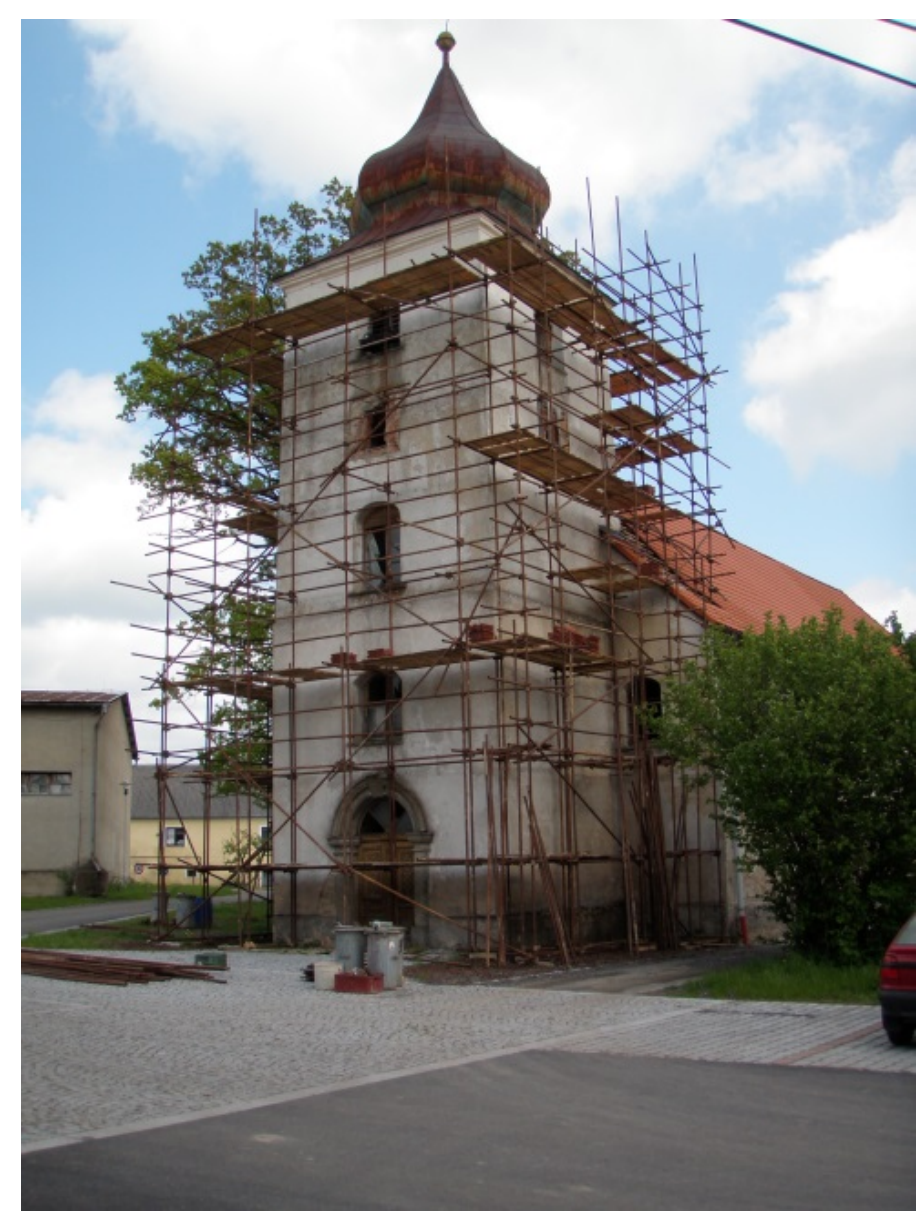

Fig 1. Village renewal. Source: The archives of the competition.

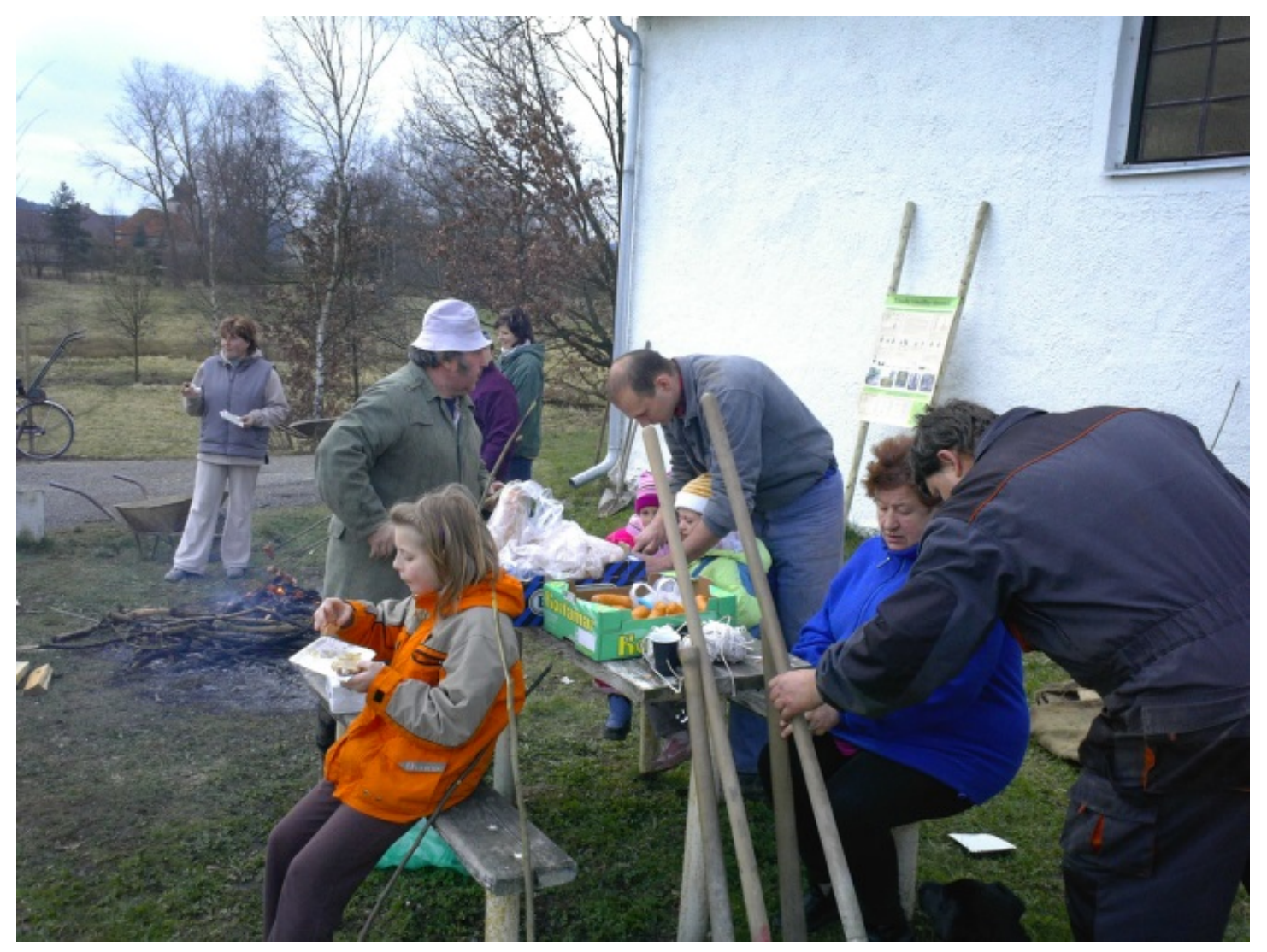

Fig 2. Community. Source: The archives of the competition. 
For children and tradition are two categories which ranked in the $3^{\text {rd }}$ and $4^{\text {th }}$ place, respectively. Both can be seen as partly overlapping with the first two categories: as figure 2 suggests, children are seen as a part of community and village renewal builds on tradition (figure 1).

The very high representation of the category for children $(\mathrm{N}=88)$ is striking in comparison to the not so frequent mentioning of other age-related categories: youth $(\mathrm{N}=22)$ and old age $(\mathrm{N}=16)$. Two explanations can be suggested here. First, a substantial share of the images coded as for children were actually images of children's playgrounds. The emphasis on this particular facility can be explained by the fact that "Support for the involvement of children and youth in community life" has been a chapter in a subsidy programme of the Ministry of regional development. In the programme documents, building of children's playgrounds is explicitly mentioned among the subsidized activities. As it is, children's playgrounds are also a visible and visually comprehensive element of rural landscape, demonstrating the municipality's openness towards children. Second, in terms of its connotative effect, the presence of children is a symbolic refutation of the lingering risks of rural depopulation and rural ageing. While the demographic evidence is mixed, there are still concerns regarding the numbers and comparative age structure of rural populations, especially in small and remote villages (NSPRV 2006). The emphasis on children serves as a powerful symbolic counterargument to these concerns.

The images coded by the category tradition refer mostly to the times before the Second World War and to rurality unspoilt by the subsequent trauma of forced collectivisation. The recollections are expressed in terms of traditional artefacts, such as folk costumes (Figure 4).

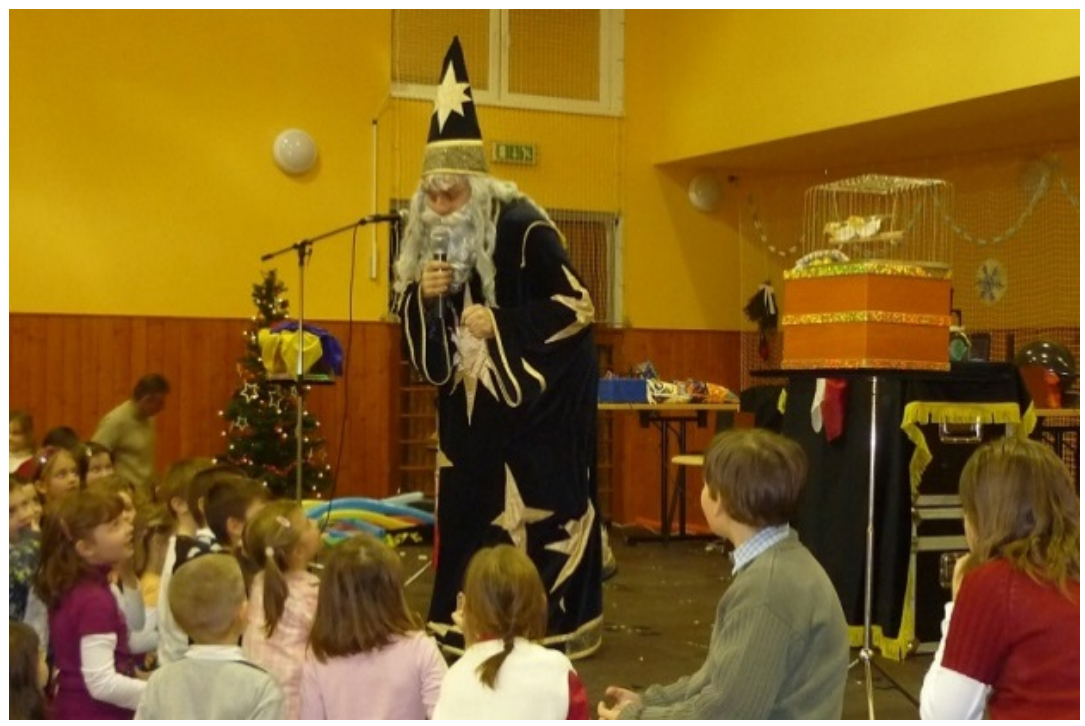

Fig 3. For children. Source: The archives of the competition.

The categories culture $(\mathrm{N}=82)$ and facilities $(\mathrm{N}=78)$ share a common implicit reference to the frame of rural deprivation (Woodward 1996) and to the rural-urban relationship. On a number of occasions, academics have discussed the relative lack of cultural events and facilities as a detriment to the rural areas in terms of their attractiveness as places for living (Majerová et al. 2005). The fact that both these categories are frequently employed in the selfpresentation of the competition participants therefore conveys a clear message to the audience. The representative images for these two categories portray a concert of classical music in what appears to be a village gym (Figure 5) and a radio tower of a mobile phone network (Figure 6). Both of these images thus represent rurality which does not lag behind its urban counterpart in terms of cultural and technical amenities. 


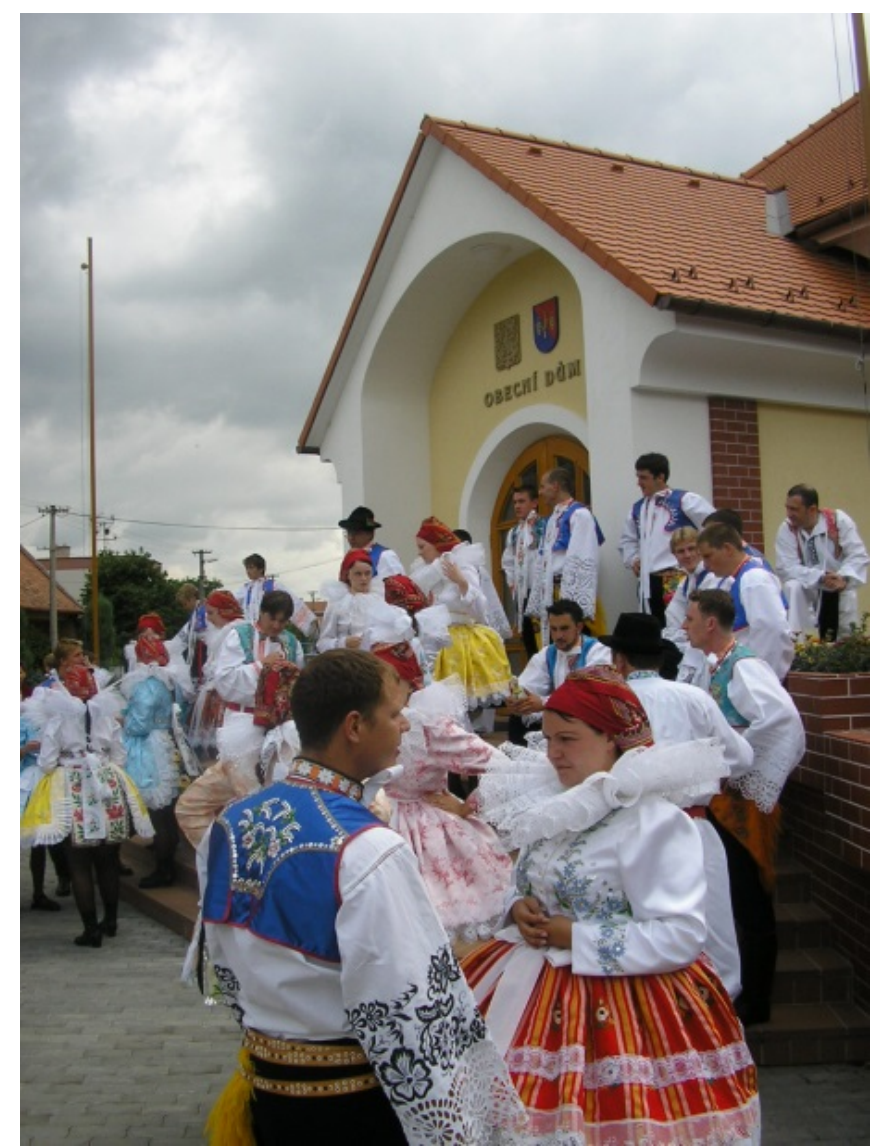

Fig 4. Tradition. Source: The archives of the competition.

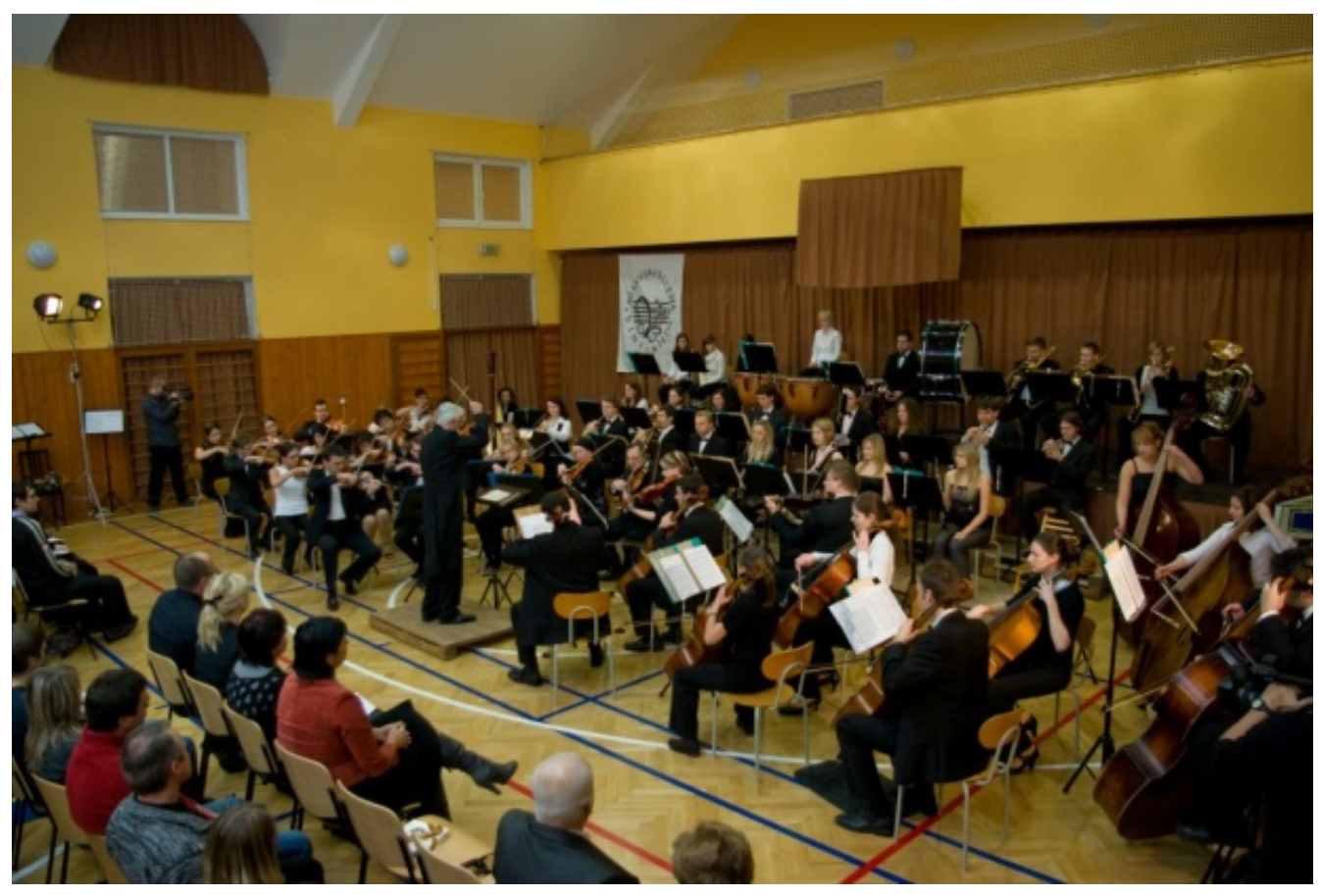

Fig 5. Culture. Source: The archives of the competition. 


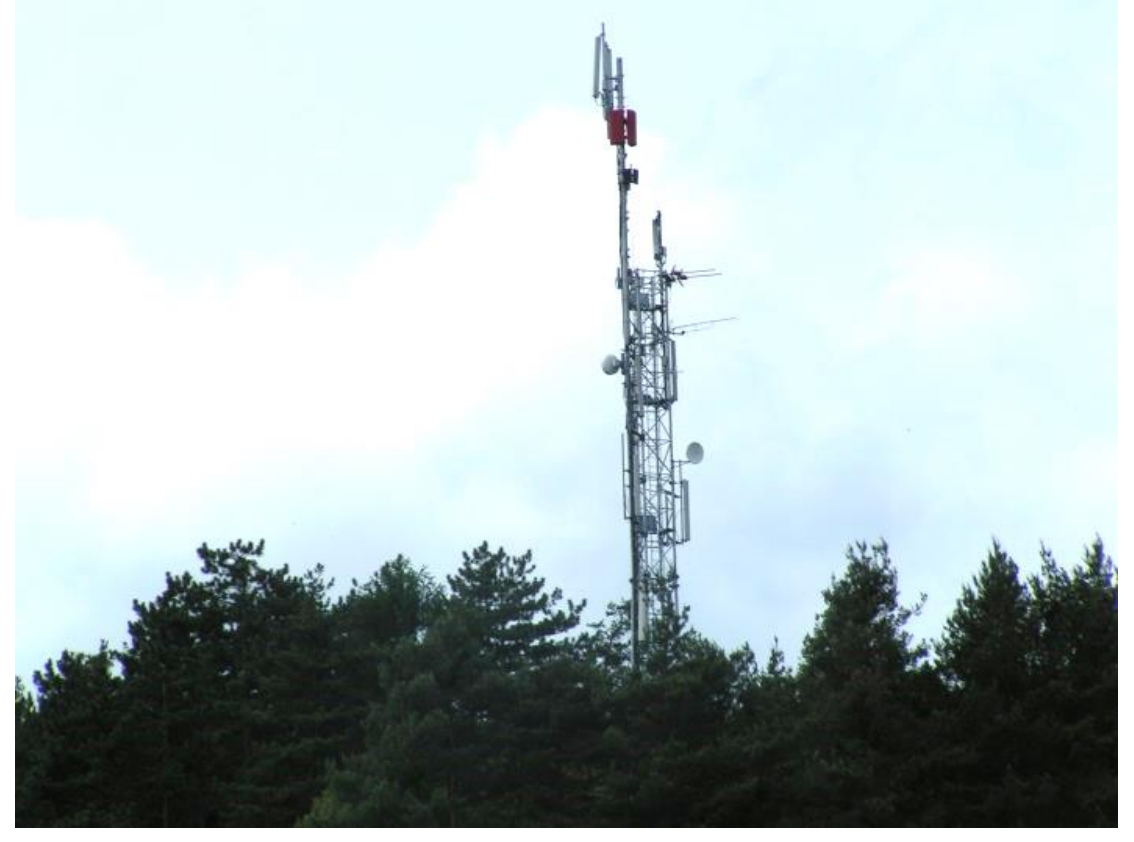

Fig 6. Facilities. Source: The archives of the competition.

In a somewhat contrasting manner, the categories nature and landmarks refer to specifically rural values. Figure 7 , which, according to the focus group members exemplifies the category Nature, shows an environment on the border of Bell's wildscape and farmscape idylls. Elements of nature, such as clear skies, grass and autumn trees are displayed together with rural settlements, traditional rural houses lined by a road. The nature which this image portrays - just like the nature portrayed by other images which the respondents have so coded - is a domesticated one. It is not a wild, adventurous, unspoiled nature to be conquered, discovered or adored. It is a nature which coexists in harmony with rural life. Figure 8, which represents the category landmarks shows what is typical for all landmark images in the sample: unlike the urban landmarks and tourist-oriented monuments, rural landmarks carry regional, local meanings and local identities. Like the building in figure 8 , their history and their meanings will only be known to local inhabitants and will often be transmitted in the form of memory, rather than formal history (see Nora 1989).

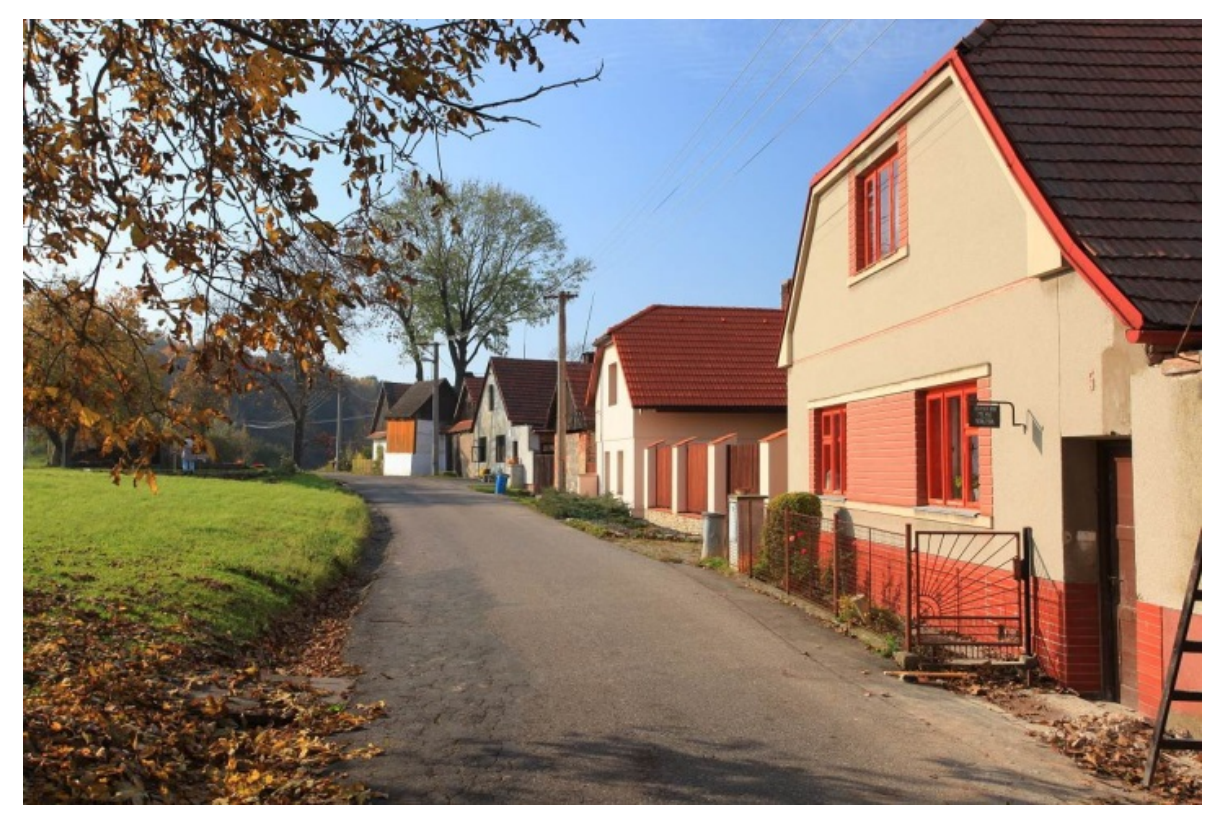

Fig 7. Nature. Source: The archives of the competition. 


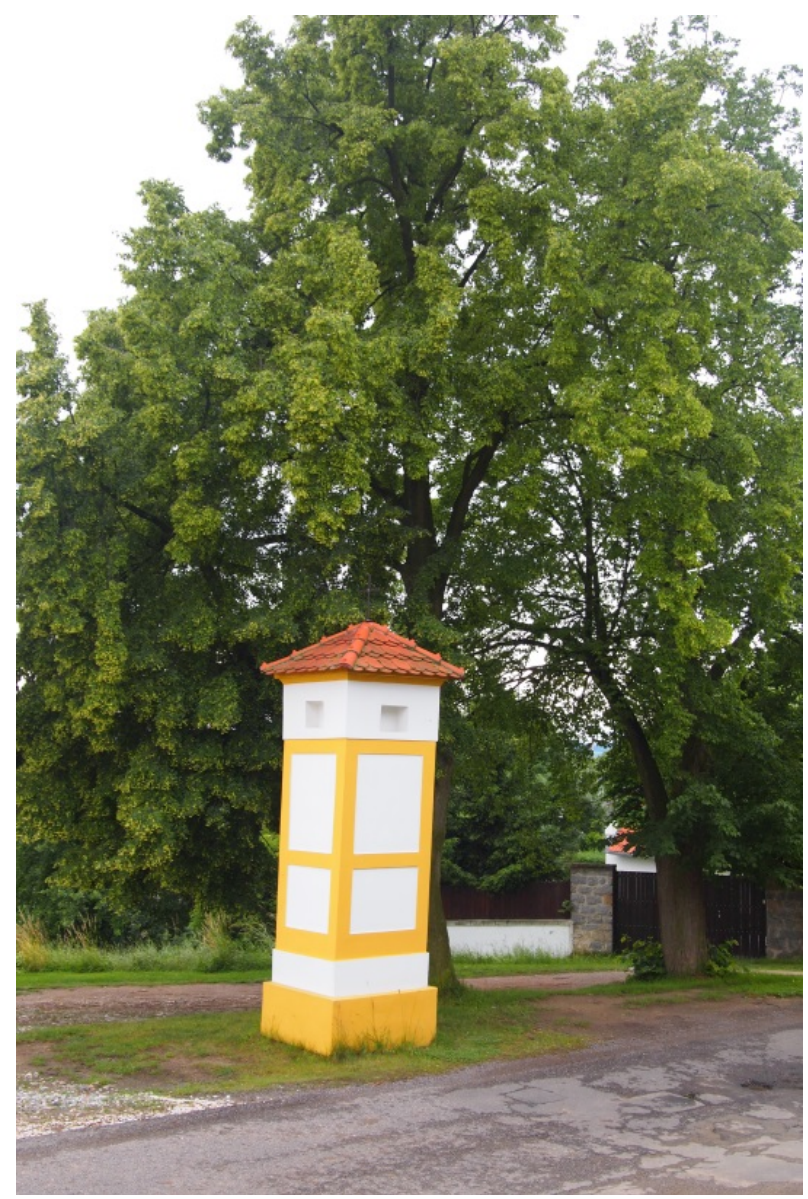

Fig 8. Landmarks. Source: The archives of the competition.

The category sport $(\mathrm{N}=42)$ represents a set of activities which also adds to the positive selfimage of villages. As Binek (2009) and Svobodová and Věžník (2014) have shown, social life in small villages has traditionally displayed a strong relation to sporting activities and many social events in rural areas are the results of the activities of sports-focused organisations (Sokol, local football clubs etc.). Figure 9 displays a sporting area with a well-equipped football stadium, a proof that the municipality is investing money to support sporting activities.

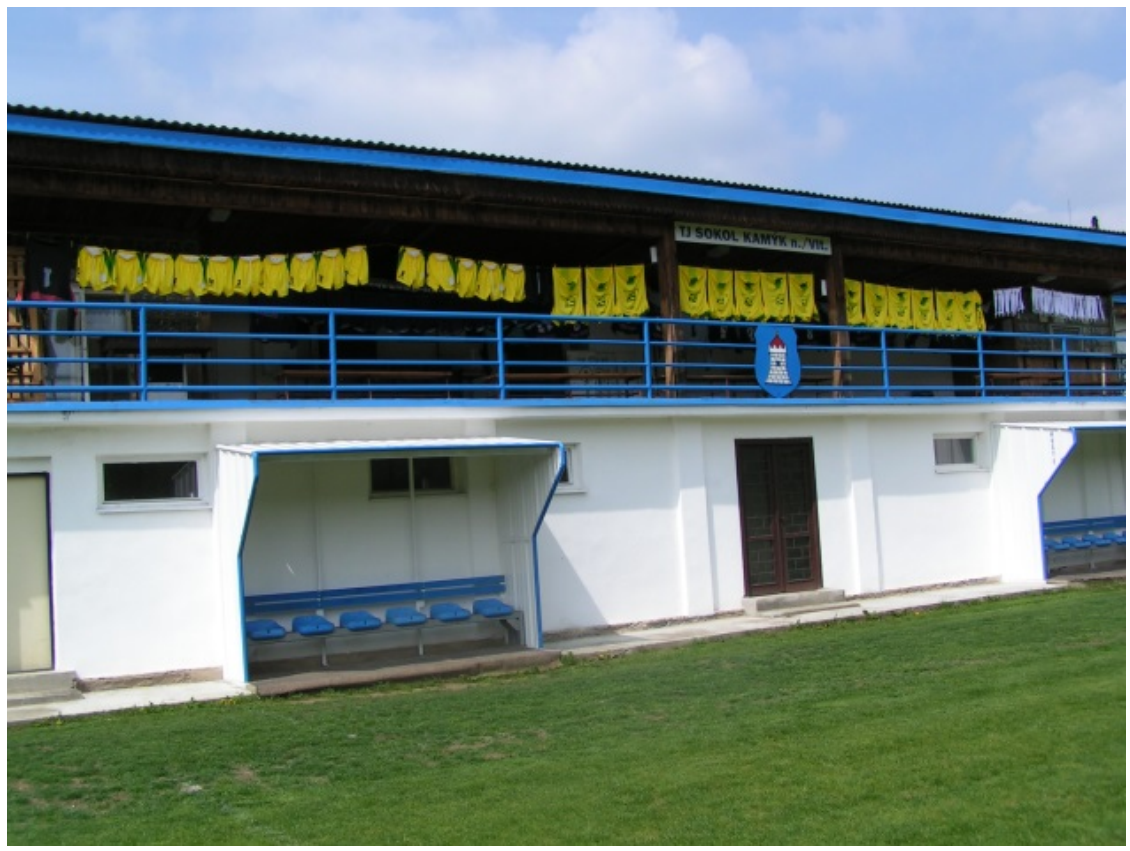

Fig 9. Sport. Source: The archives of the competition. 


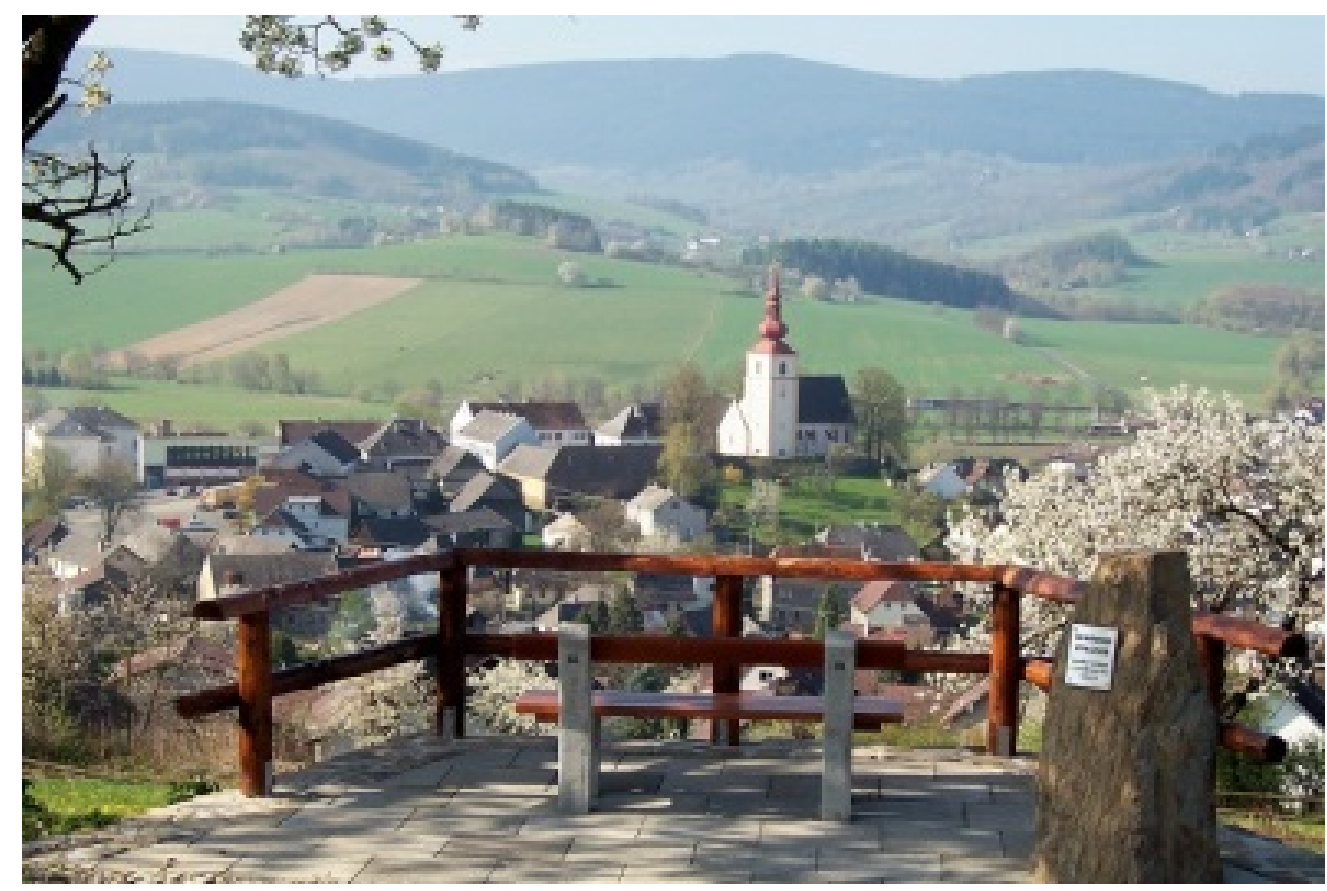

Fig 10. Landscape. Source: The archives of the competition.

The category landscape, exemplified by figure 10 , bears an immediate resemblance to what has previously been coded as nature. A comparative review of images coded with the two category codes has noted some differences, most of which were related to the formal properties of the photograph: images tagged with landscape tended to be more general shots, taken from a larger distance, incorporating larger parts of villages rather than details. Their composition also often does not rely on one central element. Apart from these formal differences, however, the iconographic content of the two categories is very similar. Nature thus appears as an element of rural landscape - and vice versa.

There are other noteworthy categories among those with $\mathrm{N}<30$. First, emptiness, a category which the respondents used to describe those rural places, which they perceived as deserted or under-used (the original codes before categorisation were empty village, a playground for noone or loneliness). Apparently, two contradictory modes of self-presentation are at play here: a rural landscape without people may be perceived as idyllic and picturesque (see fig. 7), with the absence of human element stressing its unspoiled, innocent existence. On the other hand, a similar picture (figure 11, chosen as representative for emptiness) may be understood through the lens of loneliness and emptiness, implying the image of a life-less village.

Survey findings, confirming that Czech rural inhabitants are more religious than their urban counterparts (CZSO 2014) are supported by relatively frequent depictions of the categories belief $(\mathrm{N}=25)$ and church $(\mathrm{N}=22)$. Less frequently mentioned, yet still substantial $(\mathrm{N}=17 ; \mathrm{N}=16)$, are the categories free time and leisure, two activities which, together with sports, explicitly narrate the rural as a place for consumption and leisure-oriented activities. Both these categories were seen as represented by the same photograph: figure 12 . 


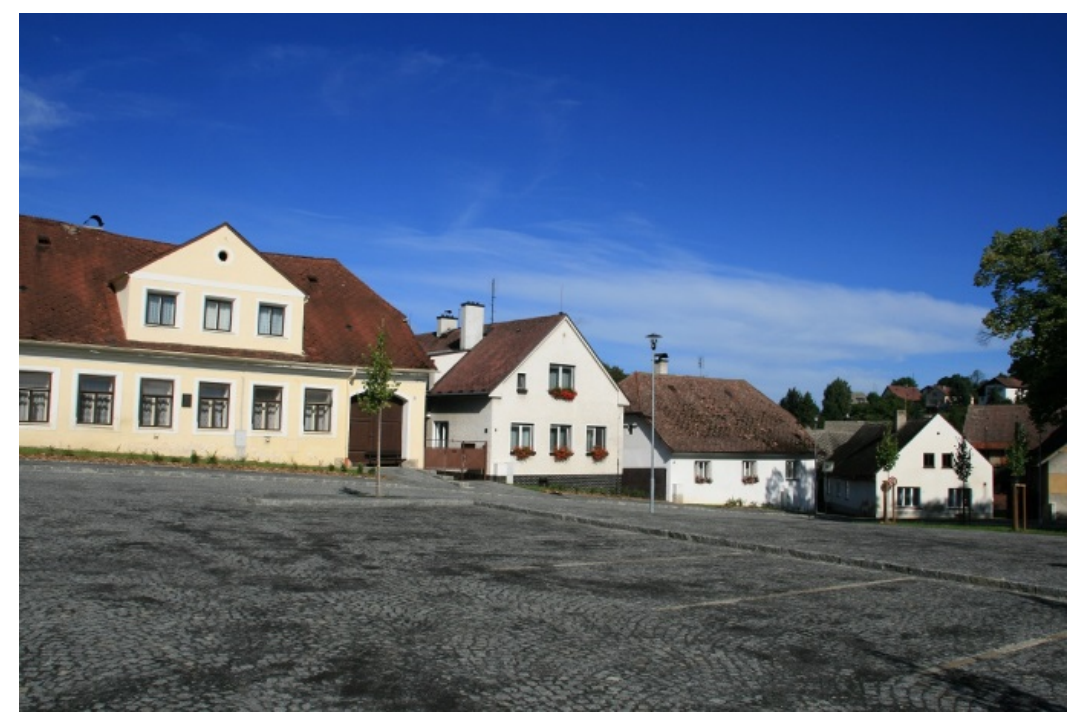

Fig 11. Emptiness. Source: The archives of the competition.

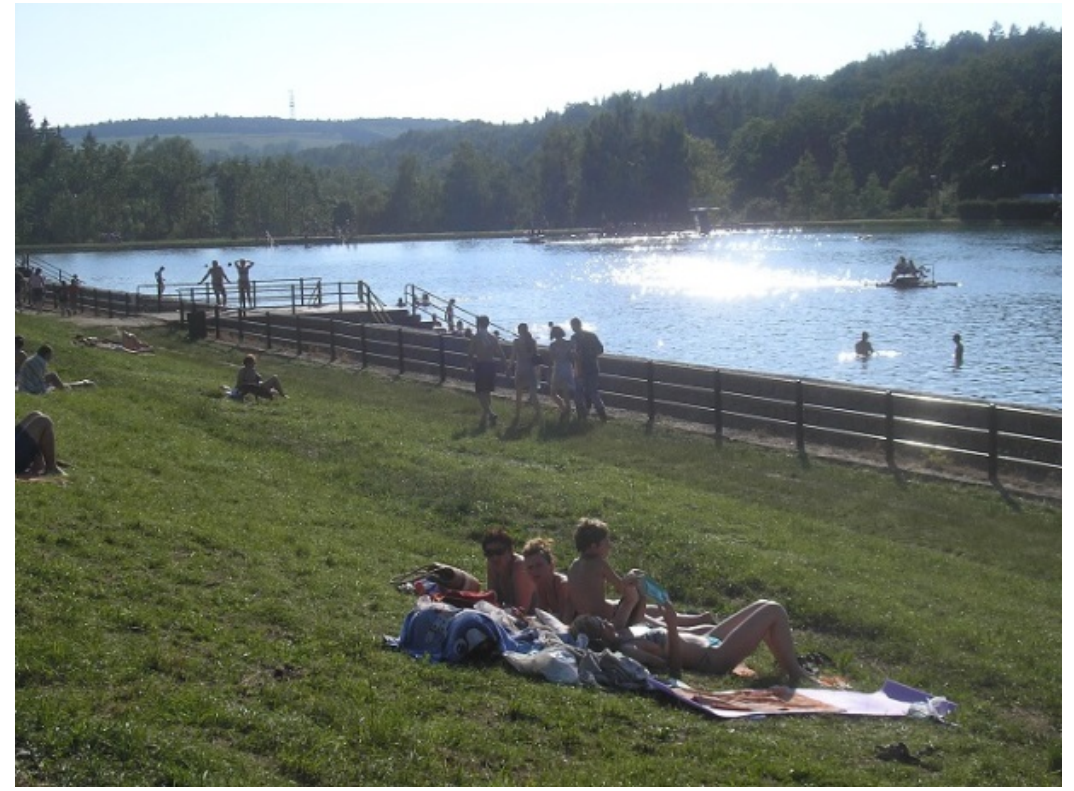

Fig 12. Free time; leisure. Source: The archives of the competition.

Some other categories from the bottom lines of table 1 are worth mentioning. Surprisingly, neglect and unattractiveness were used to code photographs, which are meant to carry positive image of rural areas and rurality. These codes were used to describe building sites and finished buildings which the respondents perceived as lacking visual appeal. The category firemen is the only substantial category which explicitly describes a specific group of rural inhabitants (not including age-based groups of children, youth and old age). It is understandable, since a large part of community life in Czech villages is connected to the activities of firemen and firemen's unions.

The second stage of the analysis has focused on the positive values associated with the kind of rural idyll presented at the pictures. Respondents had the option to identify one or more positive values represented in each picture or to leave a blank space if, in their view, the content of the picture was not associated with positive values. The positive values identified in the sample are listed in table 2, categorised into 27 meaningful categories. The categories are presented by clusters, arranged by their frequency: Formal events and activities, Informal social relations, Nature, Tradition, Family, Projects and Emotions. 


\begin{tabular}{|l|l|c|}
\hline Cluster & Category & Frequency \\
\hline Formal events and activities & Events & 125 \\
\hline & Sports & 37 \\
\hline & Culture & 25 \\
\hline & Civil society & 22 \\
\hline & Music & 9 \\
\hline & Tourism & 6 \\
\hline Informal social relations & Social relations & 75 \\
\hline & Free time & 16 \\
\hline & Informal economy & 9 \\
\hline & Care & 9 \\
\hline Nature & Nature & 59 \\
\hline & Animals & 24 \\
\hline & Green & 12 \\
\hline & Landscape & 3 \\
\hline Tradition & Tradition & 51 \\
\hline & Religion & 19 \\
\hline & Historical landmarks & 17 \\
\hline Family & Children & 77 \\
\hline & Senior citizens & 5 \\
\hline & Family & 3 \\
\hline Projects & Village renewal & 36 \\
\hline & Facilities & 11 \\
\hline Emotions & Appearance of the village & 10 \\
\hline & Emotions & 22 \\
\hline & Typical village & 6 \\
\hline & Home & 4 \\
\hline & Beauty & 2 \\
\hline
\end{tabular}

Tab 2. Positive values associate with the images.

While the 27 categories cover all answers that the respondents have provided, the seven clusters present a rather rough generalisation and should not be considered analytically. Their sole purpose is to group similar categories in the table and allow for an effective comparison with the first part of the analysis.

The results suggest what has already been hinted at in the previous section: the positive values which the villages employ in their self-presentations are tied to the everyday social life of the village, formal or informal. The three most frequent categories (events, social relations and children) are all tied to the notion of everyday social life, as well as other frequently mentioned values, such as sports, culture, civil society and free time. Values, which are not related to everyday sociability (most notably tradition and nature) have been mentioned often, yet not as often as the "social" ones. In comparison to the descriptive analysis, there is a substantially weaker emphasis on the categories in the projects cluster; this is particularly true for village renewal. Apparently, the renewal projects, while valued highly by the competition commission, are not quite as strongly anchored in the core of the rural idyll.

\section{Discussion: What is "a good village"?}

How is the image of a "good village" produced in the competition Village of the year? What are the features that villages use to present themselves as good, or even the best? The first set of results suggests that the strongest emphasis is laid on the concept of rural renewal and related 
activities. The importance of rural renewal is partly explained by the general conditions of the competition which place an emphasis on the active elements of rural life, namely local initiatives and community activities. Importantly, the prevalence of the concept as well as the other frequently used categories (community, for children and others) draws a picture where a good village is an active village. It is, therefore, not an image of a peaceful, quiet village, but rather an image of a pulsing, lively active place, which is represented in the pictures of successful applicants.

The notion of activity is also semantically related to community. In our analysis, community is the second most frequently mentioned category and, as picture 2 suggests, it entails the inclusion of various age groups in community activities, including children. This diversity of rural communities is presented only in the form of various demographic categories. None of the pictures in the analysed sample depict members of minorities or marginal groups, thus confirming their neglected status in the rural imagery (see Philo 1992). The other frequently mentioned categories can be divided into three broad clusters: traditional rurality (tradition, landmark, history), rurality in harmony with nature (nature, landscape) and a modern rurality, whose living conditions are not lagging behind those of cities (culture, sport, transport).

Doing a visual content analysis implies not only studying the actual content of what is represented but it also requires a sensitivity towards elements which are not included in the images. If we use Bell's (2006) typology of rural idylls as a point of departure, we note a striking absence of agriculture and farming-related images. The focus group has identified somewhat related categories of animals $(\mathrm{N}=7)$ and hunting $(\mathrm{N}=4)$, however an explicit reference to agricultural production is absent. This omission may be related to the long-term process, whereby agriculture has become increasingly marginal in Czech rural areas, following the 1989 Velvet revolution (Majerová et al. 2003; Pospěch 2014). New and culturally highly valued forms of ecological farming have emerged since then; these too, however, are absent in the data (category ecology is represented in 7 pictures, none of which have a connection to agriculture).

It is not only the images of farmscapes, which are missing in the visual presentations, but also the sporting adventurescapes, another type of rural idyll that Bell has identified. A general category of tourism is marginally represented $(\mathrm{N}=8)$ but other than this, it seems the images are strongly focused on local inhabitants and their everyday lives. This focus becomes all the more visible by the fact that many categories (facilities, transport, modern, entrepreneurship) describe images which, such as picture 6 , are contradictory to the images of traditional rurality, produced for the urban tourist gaze (Figueiredo \& Raschi 2011). Unlike the extraordinary experience of the tourist or the sporting effort of the adventure-seeker, the focus of the images in the competition is on the everyday, local life.

This observation is supported by the outcomes of the second part of the analysis. In comparison to the robust and reliable content analysis, the second part has been rather exploratory, as it shifted the focus from readily visible images to perceived values and emotional responses. With these limitations in mind, however, some interesting conclusions can be drawn from its results. First, as stated above, there is a substantial emphasis on the everyday life of the village. In contrast to the rural idyll identified by Duenckmann (2010) and others, the idyllic images are aimed not at the outer (urban) observer, but on the inner (local) participant. The most frequently identified positive values are based on local, rather than external resources (events, social relations, children, tradition, sports etc.). The value of village renewal, which is implicitly connected to external funding and policy programmes, is much less frequent in the second part of the analysis. References to tourism are only marginal.

There is, again, a strong emphasis on children. The positive values associated with childrenoriented activities and with the involvement of children seem to play a crucial role in the selfpresentation of the future Villages of the Year. The analysis of values also distinguishes between formal and informal social relations, which the first part conflates under the heading of community. While in everyday practice, the formal and informal domains overlap, their separation enables us to see the extremely strong positive representation or rural civil society (events, sports, culture, civil society). These findings become important in the context of the role 
of social capital as a factor of development in Czech rural areas, identified by Majerová et al. (2011).

\section{Conclusion}

The rural idyll studied in this paper, has a specific character, co-produced by the competition organisers and the rural actors themselves. Unlike the idyllic representations studied by Bell (2006), the competition images are very strongly tied to the everyday life of village inhabitants. The values which successful villages build their presentation on have very little relation to the external, out-of-the-ordinary experiences of a tourist, a visitor or an urban dweller. The selfpresentation focuses on local people and local resources and the emphasis on everyday life reminds us of the idyllic view of "my nice little village“, identified by Duenckmann (2010). Social and community life, civic society and participation are amongst the main positive values presented in the applications of the successful villages. In contrast to the iconography of rural images of the 1980s and early 1990s, there are virtually no references to agriculture.

The lack of positive images of agriculture and farming is accompanied by a rather noticeable absence of references to work in general. In the results of both parts of the analysis, there are only minimal references to the world of paid work. This stands in contrast to photographic documentations of Czech rural areas in the past, such as the work by Pokorný on the 1970s and 1980s (2012), where working life was a central element. This change can be explained with reference to the shift towards postproductivism in rural areas (Ward 1993) but it also puts the nature of rural community in question. Village community life, which has previously been structured through work and work-related activities, appears to be articulated in terms of voluntary, free time activities and elements of civil society. This observation is too general to be confirmed by our present data, yet we believe that, like the other conclusions we have presented here, it opens the door to further research on life in "good villages" and its images, which are constantly (re-)produced and negotiated in the sphere of public discussion.

References:

[1] Alexander, J. (2003). The Meanings of Social Life: A Cultural Sociology. New York: Oxford University Press.

[2] Baylina, M. \& Berg, N. (2010). Selling the countryside: Representations of rurality in Norway and Spain. European Urban and Regional Studies 17(3), 277-292. Doi: $10.1177 / 0969776409356215$.

[3] Binek, J. (2009). Synergie ve venkovském prostoru: aktéři a nástroje rozvoje venkova. Brno: GaREP.

[4] Blažek, B. (1998). Venkov, města, média. Praha: Slon.

[5] Bell, D. (1997). Anti-idyll: rural horror (pp. 91-104). In: Cloke, P. \& Little, J., eds., Contested Countryside Cultures: Otherness, Marginalisation, and Rurality. London: Routledge.

[6] Bell, D. (2006). Variations on the rural idyll (pp. 149-161). In: Cloke, P., Marsden, T., Mooney, P. H., eds., Handbook of Rural Studies. Sage, London.

[7] Bell, M. (2007). The two-ness of rural life and the ends of rural scholarship. Journal of Rural Studies 23, 402-415. Doi:10.1016/j.jrurstud.2007.03.003.

[8] Brandth, B. (1995). Rural masculinity in transition: Gender images in tractor advertisements. Journal of Rural Studies 11(2), 123-133. Doi: 10.1016/07430167(95)00007-A.

[9] Chaplin, E. (1994). Sociology and Visual Representation. London, New York: Routledge.

[10] Cloke, P. (1997). Country Backwater to Virtual Village? Rural Studies and 'The cultural turn'. Journal of Rural Studies 13(4), 367-375. Doi: 10.1016/S0743-0167(97)00053-3. 
[11] Cloke, P. (2006). Conceptualizing Rurality. In Cloke, Paul J., Mardsen, T. \& Mooney, P. (eds.). Handbook of Rural Studies (Pp. 18-28). Thousand Oaks, Calif.: SAGE.

[12] Cloke, P., \& Little, J. (Eds.) (1997). Contested Countryside Cultures: Otherness, Marginalisation, and Rurality. London: Routledge.

[13] Collier, J. \& Collier, M. (1990). Visual anthropology. Albuquerque: University of New Mexico Press.

[14] CZSO (2014). Náboženská víra obyvatel podle výsledků sčítání lidu. Prague: Czech Statistical Office. Available at http://www.czso.cz/csu/2014edicniplan.nsf/t/82002D3492/\$File/17022014.pdf.

[15] Duenckmann, F. (2010). The village in the mind: Applying Q-methodology to reconstructing constructions of rurality. Journal of Rural Studies 26, 284-295. Doi: 10.1016/j.jrurstud.2010.01.003.

[16] Erjavec, K., Erjavec, E. \& Juvančič, L. (2009). New wine in old bottles: critical discourse analysis of the current common EU agricultural policy reform agenda. Sociologia Ruralis 49(1), 41-55. Doi: 10.1111/j.1467-9523.2008.00477.x.

[17] Figueiredo, E. \& Raschi, A. (2011). "Un' immensa campagna avvolta dal verde" Reinventing rural areas in Italy through tourism promotional images. European countryside 3(1), 1-20. Doi: 10.2478/v10091-011-0001-4.

[18] Halfacree, K. (1993). Locality and social representation: space, discourse and alternative definitions of the rural. Journal of Rural Studies 9 (1), 23-37. Doi: 10.1016/07430167(93)90003-3.

[19] Halfacree, K. H. (1995). Talking about rurality: social representations of the rural as expressed by residents of six English parishes. Journal of Rural Studies 11 (1), 1-20. Doi: 10.1016/0743-0167(94)00039-C.

[20] Hrabánková, M. (1997). Vize rozvoje venkovského prostoru na přelomu tisíciletí (pp. 3034). In Český venkov na přelomu tisíciletí. Praha: Czech University of Life Sciences.

[21] Jones, O. (1995). Lay discourses of the rural: developments and implications for rural studies. Journal of Rural Studies 11(1), 35-49. Doi: 10.1016/0743-0167(94)00057-G.

[22] Krippendorf, K. (1980). Content Analysis: An Introduction to its Methodologies. London: Sage.

[23] Librová, H. (1996). Decentralizace osídlení - vize a realita. Část první: vize, postoje k venkovu a potenciální migrace v ČR. Sociologický časopis 32(3), 285-296.

[24] Lutz, C. \& Collins, J. (1993). Reading National Geographic. Chicago: University of Chicago Press.

[25] Majerová, V. (2006). Změny českého venkova z pohledu sociologických výzkumů (pp. 403409). In Majerová, V., ed., Venkov je náš svět - sborník př́spěvků z mezinárodní konference Praha: Czech University of Life Sciences.

[26] Majerová, V. et al. (2003). Český venkov 2003: situace před vstupem do EU. Praha: Česká zemědělská univerzita.

[27] Majerová, V. et al. (2005). Český venkov 2005: rozvoj venkovské společenosti. Praha: Česká zemědělská univerzita.

[28] Majerová, V., Kostelecký, T. \& Sýkora, L. (2011). Sociální kapitál a rozvoj regionu: př́iklad kraje Vysočina. Praha: Grada.

[29] Marsden, T., Lowe, P. \& Whatmore, S. (1990). Rural restructuring: global processes and their responses. London: David Fulton.

[30] Mingay, G. E, ed. (1989). The Rural Idyll. London: Routledge. 
[31] Moscovici, S. \& Duveen, G. (2000). Social representations: explorations in social psychology. Cambridge: Polity press.

[32] Nash, K. (2001). The 'Cultural Turn' in Social Theory: Towards a Theory of Cultural Politics. Sociology 35(1), 77-92. Doi: 10.1177/0038038501035001006.

[33] Nora, P. (1989). Between memory and history. Representations 26, 7-24. Doi: $10.2307 / 2928520$.

[34] NSPRV (2006). Národní strategický plán rozvoje venkova České republiky na období 20072013. Prague: Ministry of Agriculture.

[35] Panofsky, E. (1981). Význam ve výtvarném umění. Praha: Odeon.

[36] Phillips, M., Fish, R. \& Agg, J. (2001). Putting together ruralities: towards a symbolic analysis of rurality on the British mass media. Journal of Rural Studies 17 (1), 1-27. Doi: 10.1016/S0743-0167(00)00015-2.

[37] Philo, C. (1992). Neglected rural geographies: a review. Journal of Rural Studies 8(2), 193207. Doi: 10.1016/0743-0167(92)90077-J.

[38] Pokorný, M. (2012). Venkov (1973-1988): Novohradsko. Praha: Triton.

[39] Pospěch, P. (2014). Discursive no man's land: Analysing the discourse of the rural in the transitional Czech Republic. Journal of Rural Studies 34(4), 96-107. Doi: 10.1016/j.jrurstud.2014.01.006.

[40] Rose, G. (2001). Visual methodologies: an introduction to the interpretation of visual materials. London: SAGE.

[41] Short, B. (1992). The English rural community: Image and analysis. Cambridge: Cambridge University Press.

[42] Svendsen, G. (2004). The right to development: construction of a non-agriculturalist discourse of rurality in Denmark. Journal of Rural Studies 20, 79-94. Doi: 10.1016/S07430167(03)00045-7.

[43] Svobodová, H. \& Věžník, A. (2014). Úvod do geografie venkova. Brno: Masarykova univerzita.

[44] Sztopmka, P. (2005). Vizuální sociologie. Praha: SLON.

[45] Urry, J. (1990). The Tourist Gaze: Leisure and Travel in Contemporary Societies. Newbury Park: Sage Publications.

[46] Vepsäläinen, M. \& Pitkänen, K. (2010). Second home countryside. Representations of the rural in Finnish popular discourses. Journal of Rural Studies 26(4), 194-204. Doi: 10.1016/j.jrurstud.2009.07.002.

[47] Vobecká, J. (2009). Czech rural development policies for human resources after 2004: a story of muddled definitions preventing strategic visions. Central European Journal of Public Policy 3(1), 44-65.

[48] Ward, N. (1993). The agricultural treadmill and the rural environment in the postproductivist era. Sociologia Ruralis 33 (3-4), 348-364. Doi: 10.1111/j.14679523.1993.tb00969.x.

[49] Williams, R. (1973). The country and the city. Oxford: Oxford university press.

[50] Winchester, H. \& Rofe, M. W. (2005). Christmas in the 'Valley of Praise': Intersections of the rural idyll, heritage and community in Lobethal, South Australia. Journal of Rural Studies 21 (3), 265-279. Doi: 10.1016/j.jrurstud.2005.05.008.

[51] Winther, M. \& Svendsen, G. (2012). 'The Rotten Banana' fires back: The story of a Danish discourse of inclusive rurality in the making. Journal of Rural Studies 28(4), 466-477. Doi: 10.1016/j.jrurstud.2012.05.003.

[52] Woods, M. (2005). Rural geography. London: SAGE. 
[53] Woods, M. \& McDonagh, J. (2011). Rural Europe and the world: globalization and rural development. European Countryside 3(3), 153-163. Doi: 10.2478/v10091-012-0001-z.

[54] Woodward, R. (1996). "Deprivation" and "the rural": an investigation into contradictory discourses. Journal of Rural Studies 12(1), 55-67. Doi: 10.1016/0743-0167(95)00048-8. 